\title{
Effect of farmyard manure and inorganic fertilizers on maize production on Alfisols and Ultisols in Kakamega, western Kenya
}

\author{
${ }^{1}$ Achieng, J. O., ${ }^{2}$ Ouma, G. ${ }^{*}{ }^{2}$ Odhiambo, G and ${ }^{1}$ Muyekho, F \\ ${ }^{1}$ Kenya Agricultural Research Institute, P. O. Box 169-50100, Kakamega, Kenya \\ ${ }^{2}$ Maseno University, Private Bag, Maseno, Kenya
}

\begin{abstract}
Soil acidity is one property associated with decline of most crop productivity. Alfisols and Ultisols are some of the acidic soils predominant in western Kenya. An experiment was conducted in both soils to find out the effect of farmyard manure (FYM) and inorganic fertilizers on maize yield on farmers' fields during wet and dry seasons of 2006. The experiment, laid out in a randomized complete block design (RCBD), had five replications in each soil type. The treatments were: farmer's practice, $\mathrm{N}\left(60 \mathrm{~kg} \mathrm{ha}^{-1}\right), \mathrm{NP}\left(60 \mathrm{~kg} \mathrm{ha}^{-1}\right.$ of each), NPK (60 kg ha ${ }^{-1}$ of each N and P; K 40 $\mathrm{kg} \mathrm{ha}^{-1}$ ), FYM+30 kg N ha-1, and optimal fertilizer (N, 200; P, 60; K, 120; Mg, 20; B, $5 \mathrm{~kg} \mathrm{ha}^{-1}$ ). During wet season, all treatments in Alfisols gave nearly double grain yield compared to Ultisols. In both soils, during the same season, except for optimal fertilizer, FYM was not significantly $(P \leq 0.05)$ different from other inorganic fertilizer treatments on plant population, height, cob number, stover, grain yield and 100 -seed weight. FYM had a $108 \%$ and $103 \%$ grain yield advantage over farmer's treatment in Alfisols and Ultisols, respectively. During dry season, plant population, number of cobs and grain yield were higher in Ultisols compared to Alfisols. In each soil type, FYM plus $30 \mathrm{~kg} \mathrm{~N}^{-1}$ provided maize grain yield equivalent to that of N, NP and NPK treatments. FYM had a 4\% grain yield advantage over optimal and NPK treatments on Ultisols during dry season. We conclude that larger amount of fertilizers or liming is needed on Ultisols to enhance their productivity to the level of Alfisols and that due to the fact that smallholder farmers are not likely to afford large amount of fertilizer and liming, use of FYM is their best bet for maize production on both Alfisols and Ultisols as there is no significant yield advantage from N, NP or NPK over FYM. Ultisols appear to be more responsive to FYM during dry season probably due to prevailing higher temperatures and relatively dry soil which enhances faster mineralization of organic matter to available plant nutrients. Addition of $\mathrm{N}$ fertilizer failed to increase yield in Ultisols, probably due to decline in soil $\mathrm{pH}$ and consequently inefficient utilization of applied resources.
\end{abstract}

Keywords: Farmyard manure, maize, Alfisols, Ultisols, Fertilizers

\section{INTRODUCTION}

Biophysical and socioeconomic are among the principal factors affecting soil productivity potential in sub Sahara Africa. Factors like weathering, depletion of soil carbon, intensive and continuous cropping practices on Alfisols, Oxisols and Ultisols have resulted in rapid decline of nutrients in soil organic matter (Hossner and Juo, 1999; Juo, et al. 1995). Such serious threats to agricultural productivity have been identified as major causes of decreased crop yields in all regions within sub Saharan Africa (Henao and Baanante, 2006).

Nitrogen and phosphorus are the main limiting nutrients in food crop production in western Kenya (Shepherd et al., 1997) though potassium deficiencies are locally important. One of the ways of addressing the impact of soil mining is use of inorganic fertilizers, but use of these inputs among smallholder farmers is currently very low, and is not expected to increase significantly in the near future. High fertilizer costs, marketing problems and poor infrastructures are some of the major reasons for low use of fertilizer. Moreover, continuous use of mineral fertilizer can have detrimental effects on soil properties. On strongly weathered, poorly buffered soils of the tropics like Kaolinitic, Alfisols, Ultisols and Oxisols, using inorganic fertilizer as the main source of nutrients can lead to rapid decline in crop yields because of acidification and soil compaction. Application of ammonium based fertilizers such as Ammonium Sulphate, Ammonium Nitrate and to a limited extent Urea, aggravates soil acidity (Lungu and Dynoodt, 2008). 
High rates of lime and phosphatic fertilizers are required to improve crop yields on highly acidic soils. A large percent of agriculture in western Kenya, where acid soils predominate, is practiced by smallholder, resource-poor farmers who are not able to purchase large quantities of lime and/or fertilizers. Many studies have indicated that addition of organic residues to acid soils can reduce Al toxicity (hence lowering the lime requirement) and enhance $P$ availability (Chukwuka and Olabode et al. 2007; Liasu et al. 2008; Nziguheba et al. 2002; Omotayo, 2009).

The use of resources available on farm is increasingly gaining importance among smallholder farmers. Such resources include crop residues, green manure, compost and farm yard manure. Retention of crop residues on land has potential to increase soil $\mathrm{pH}$. However, crop residues are usually burned rather than ploughed-in because they interfere with land preparation. But still, the ash itself, being alkaline, has a neutralizing effect on the soil (Stroomgard, 1991).

Among the organic sources, farmyard manure (FYM) is most important as it contains all the nutrients needed for crop growth including trace elements, albeit in small quantities. The efficiency of manure utilization by a crop is determined by the method of application, time to incorporation and the rate of decomposition in the soil. Characteristically, not all of the nutrients in manure are directly available after its incorporation in the soil. Organic forms of nutrients must first be mineralized into plant-available forms such as nitrate. The rate of mineralization is variable and depends on soil type, moisture, temperature, and manure composition. When cow dung and urine are mixed, a balanced nutrition is made available to the plants. Swift, et al. (1994) observed that in households where crop and livestock production are integrated, FYM can become a major nutrient source for food crops and reduce the need for fertilizers.

In view of un-affordability of fertilizer due to escalating prices, more smallholder farmers in sub Sahara Africa are anticipated to turn to the use of organic sources that are not only available but also affordable, rather than inorganic fertilizers for enhancing crop productivity. This study was conducted to establish the influence of farmyard manure on maize yield on Alfisols and Ultisols in western Kenya.

\section{MATERIALS AND METHODS}

The study site: The study site is presented on Fig. 2. Farm sizes range from 0.3-1.0 ha with a mean of 0.5 per household. Many households have a few heads of zebu cows although graded dairy cows are also owned by some individuals. The area is characterized by low input low output farming. The average maize yield fluctuate around 1.0 to $1.5 \mathrm{t} \mathrm{ha}^{-1}$ year $^{-1}$.

The climatic data of the study site is presented on table 1 . The region has a bi-modal rainfall pattern: the long rainy season in March to June and the short season in September to November (Fig. 1). The high amount of rainfall received annually and intensive cultivation causes rampant soil erosion and leaching, partly responsible for soil degradation. The daily temperatures and solar radiation for the region are very conducive for production of maize, and indeed, many other tropical crops.

Table 1. Climatic data showing Rainfall, Rainy Days, Temperature and Solar Radiation at KARI Kakamega Station and surrounding areas for the period 1979-2008.

\begin{tabular}{|c|c|c|c|c|c|c|c|c|c|}
\hline \multirow[t]{3}{*}{ Month } & \multicolumn{2}{|c|}{ Rainfall (mm) } & \multicolumn{2}{|c|}{ Rainy Days } & \multicolumn{4}{|c|}{ Temperature $\left({ }^{\circ} \mathrm{C}\right)$} & \multirow{2}{*}{$\begin{array}{c}\begin{array}{c}\text { Solar Radiation } \\
\left(\mathrm{MJ} / \mathrm{M}^{2}\right)\end{array} \\
1980-90\end{array}$} \\
\hline & 2006 & 1979-2008 & 2006 & 1979-2008 & & & & & \\
\hline & & & & & Max & Min & Max & Min & \\
\hline Jan & 32.4 & 79.7 & 4 & 8 & 30.4 & 15.1 & 28.4 & 13.5 & 46.58 \\
\hline Feb & 98.8 & 66.5 & 4 & 8 & 31.2 & 16.0 & 29.3 & 14.2 & 41.29 \\
\hline Mar & 253.4 & 170.0 & 19 & 12 & 28.0 & 15.4 & 29.0 & 14.8 & 44.14 \\
\hline Apr & 449.1 & 256.0 & 3 & 17 & 26.7 & 15.2 & 27.1 & 15.3 & 36.17 \\
\hline May & 201.5 & 249.3 & 20 & 20 & 29.9 & 15.2 & 26.6 & 14.9 & 39.86 \\
\hline Jun & 222.6 & 160.7 & 18 & 16 & 26.6 & 14.4 & 25.9 & 14.0 & 38.17 \\
\hline Jul & 159.1 & 152.8 & 16 & 15 & 26.5 & 14.8 & 25.7 & 13.6 & 39.78 \\
\hline Aug & 111.6 & 210.3 & 16 & 17 & 26.9 & 14.9 & 26.2 & 13.6 & 40.70 \\
\hline Sep & 222.3 & 173.4 & 18 & 15 & 27.3 & 14.1 & 27.0 & 13.4 & 41.64 \\
\hline Oct & 114.9 & 147.8 & 14 & 16 & 28.1 & 14.5 & 27.1 & 14.2 & 41.56 \\
\hline Nov & 283.5 & 152.7 & 19 & 13 & 26.1 & 15.0 & 26.8 & 14.5 & 39.70 \\
\hline Dec & 194.3 & 40.1 & 17 & 8 & 26.1 & 15.2 & 27.5 & 14.1 & 45.18 \\
\hline Total & 2343.5 & 1859.3 & 165 & 171 & & & & & \\
\hline
\end{tabular}


Agric. Biol. J. N. Am., 2010, 1(4): 430-439
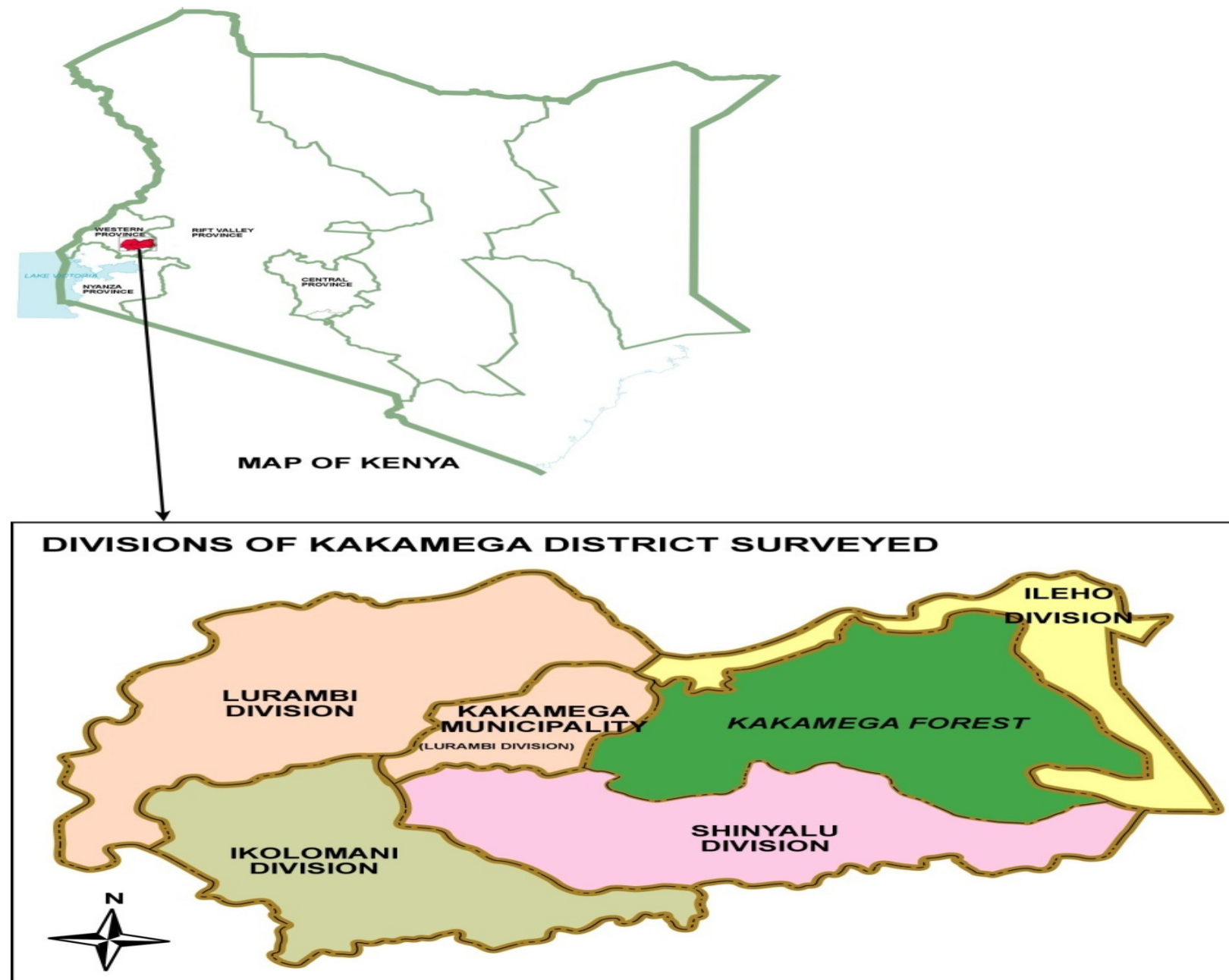

Map of Study site

The soils are predominantly Alfisols and Ultisols. Alfisols are relatively high in native fertility as $\mathrm{Ca}, \mathrm{Mg}$ and $\mathrm{K}$ have not been seriously leached. They are moderately acidic but are responsive to fertilizer application. Ultisols, on the other hand are strongly leached, acidic soils with low native fertility. Both soils are known to be severely deficient in $\mathrm{N}$ and $\mathrm{P}$ nutrients (Wikipedia, 2008). Although there are pockets of fertile soil in the region, about $85 \%$ of the land is not fertile due to acidity. Characterization of soils in study site is presented on table 2 .

Methodology: The experiment was planted on ten farms during wet (long) and dry (short) seasons of
2006 on Alfisols and Ultisols soils in Kakamega, western Kenya. Six treatments were compared on their influence on maize yield (Table 3 ). Experimental units measuring $19.5 \mathrm{~m}^{2}$ each were demarcated on each farm. Maize hybrid 614 was planted during the long (wet) season while hybrid513 was planted during the short (dry) season. The crop was planted at a spacing of $75 \mathrm{~cm} \times 30 \mathrm{~cm}$, two seeds per hole but later thinned to 1 seedling per hill. Wet season crop was planted early in March, 2006, while the dry season one was planted in mid September, 2006. Apart from farmer's practice, all other treatments were weeded twice by hand each season to effectively control the weeds. 
Agric. Biol. J. N. Am., 2010, 1(4): 430-439

Table 2. Chemical characterization of Alfisols and Ultisols in Kakamega, western Kenya.

\begin{tabular}{|c|c|c|c|c|c|c|c|}
\hline \multirow[t]{2}{*}{ Farm No. } & \multicolumn{7}{|c|}{ Alfisols } \\
\hline & $\mathrm{pH}$ & $\% \mathrm{C}$ & $\% \mathrm{~N}$ & $\mathrm{P}$ & $\mathrm{K}$ & $\mathrm{Ca}$ & $\mathrm{Mg}$ \\
\hline 1 & 5.0 & 2.7 & 0.2 & 19.8 & 119.7 & 822.5 & 303.0 \\
\hline 2 & 4.9 & 2.5 & 0.1 & 13.1 & 159.0 & 639.7 & 93.0 \\
\hline 3 & 6.1 & 2.4 & 0.1 & 19.2 & 55.4 & 1634.0 & 99.5 \\
\hline 4 & 5.9 & 1.6 & 0.1 & 33.0 & 77.2 & 789.4 & 98.4 \\
\hline 5 & 5.9 & 1.6 & 0.1 & 32.6 & 106.4 & 859.0 & 86.8 \\
\hline \multirow[t]{2}{*}{ Mean } & 5.6 & 2.2 & 0.1 & 23.6 & 103.5 & 948.9 & 136.2 \\
\hline & \multicolumn{7}{|c|}{ Ultisols } \\
\hline 1 & 4.7 & 6.8 & 0.3 & 5.0 & 237.4 & 2320.1 & 246.1 \\
\hline 2 & 5.0 & 6.0 & 0.3 & 3.7 & 207.0 & 983.8 & 201.8 \\
\hline 3 & 5.7 & 5.8 & 0.2 & 2.9 & 236.2 & 2800.0 & 430.0 \\
\hline 4 & 4.7 & 6.8 & 0.3 & 19.2 & 457.9 & 2837.8 & 364.6 \\
\hline 5 & 5.7 & 5.6 & 0.2 & 3.0 & 166.7 & 1721.6 & 280.8 \\
\hline Mean & 5.2 & 6.2 & 0.3 & 3.6 & 261.0 & 2132.7 & 304.7 \\
\hline
\end{tabular}

Table 3. List of treatments

\begin{tabular}{|c|c|}
\hline $\begin{array}{l}\text { Treatment } \\
\text { Name }\end{array}$ & Description \\
\hline $\begin{array}{l}\text { Farmer's } \\
\text { practice* }\end{array}$ & $\begin{array}{l}\text { Non-improved variety (or recycled } \\
\text { seed), inadequate fertilizer, low } \\
\text { population, inadequate weed control }\end{array}$ \\
\hline $\mathbf{N}$ & $\begin{array}{l}\text { Source: Urea, applied at } 60 \mathrm{~kg} \mathrm{ha}^{-1}, 1 / 2 \text { of } \\
\mathrm{N} \text { at planting, other } 1 / 2 \text { five weeks after } \\
\text { emergence, weed-free throughout }\end{array}$ \\
\hline NP & $\begin{array}{l}\text { Source: Urea and TSP, each applied at } \\
60 \mathrm{~kg} \mathrm{ha}^{-1} \text {, all } \mathrm{P} \text { and } 1 / 2 \text { of } \mathrm{N} \text { at planting, } \\
\text { remainder at applied five weeks after } \\
\text { emergence, weed-free throughout }\end{array}$ \\
\hline NPK & $\begin{array}{l}\text { Source: Urea, TSP and } \mathrm{KCl} ; \mathrm{N} \text { and } \mathrm{P} \\
\text { applied at } 60 \mathrm{~kg} \text { ha- } 1 \text {, all } \mathrm{P} \text { and } 1 / 2 \mathrm{~N} \text { at } \\
\text { planting, remainder at five weeks after } \\
\text { emergence, } \mathrm{K} \text { applied at planting at } 40 \\
\mathrm{~kg} \mathrm{ha}^{-1} \text {. Weed-free throughout }\end{array}$ \\
\hline$F Y M+1 / 2 N$ & $\begin{array}{l}\text { Farmyard manure applied and } \\
\text { incorporated at } 5 \mathrm{t} \mathrm{ha}^{-1} \text { before planting; } \\
\mathrm{N} \text { (source Urea) applied at the rate of } \\
30 \mathrm{~kg} \mathrm{ha}^{-1} \text { five weeks after emergence; } \\
\text { weed-free throughout. }\end{array}$ \\
\hline Optimal & 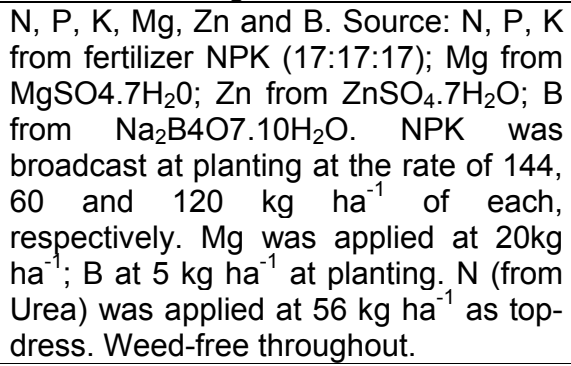 \\
\hline
\end{tabular}

${ }^{*}$ Farmer's practice (control) treatment was not included during short rainy season as participating farmers did not plant maize
The experimental design was Randomized Complete Block Design. Each of the five farms on each soil type acted as a replicate. Each plot size was $19.5 \mathrm{~m}^{2}$ but the net plot was $13.5 \mathrm{~m}^{2}$. 'Farmer's practice' treatment was detached from the rest of the plots as it was superimposed on the farmer's crop. At physiological maturity stage, all maize plants within the net plot in each treatment were counted to give plant population at harvest time. Ten plants, randomly sampled from each plot, were cut at the soil surface. Plant height was taken by measuring the length of each plant from the base of the stem to the tip of the longest tassel branch. Average height of 10 plants was taken as plant height of each treatment. At harvesting, all ears from each net plot were dehusked and the cobs counted. This gave the mean number of cobs per treatment. Field weight was obtained by weighing all ears from each net plot. Ten cobs were randomly sampled and shelled; moisture content of the grain was immediately taken and a sample of the grain packed, labeled and taken to the laboratory for drying. Drying was repeated for several days until moisture content of $13.5 \%$ was reached. Shelling percentage was obtained from the 10 shelled cobs by dividing fresh grain weight against fresh cob (including grain) weight. Field weight, moisture content and shelling percentage were used to calculate grain yield per treatment. Ten sample plants were randomly cut at the soil surface, cobs were removed then stover was chopped into small pieces, weighed and recorded. A sub-sample was taken, weighed and dried continuously in the laboratory until a constant weight was reached. Both 
sample and sub sample dry weight was used to calculate stover yield for each treatment.

Data was subjected to ANOVA using the GenStatDiscovery Edition 3, and $\mathrm{LSD}_{0.05}$ tests separating statistical significant means.

\section{RESULTS}

\section{(i) Wet season}

Plant population:Treatment was significant on maize population at harvest $(P \leq 0.001)$. Apart from farmers' practice, which gave the lowest plant stand $\left(22,151\right.$ plants ha $\left.^{-1}\right)$ all other treatments were not statistically different (Table 4). In general, population was very low due to heavy rainfall accompanied by strong winds which lodged the plants mid-season (Table 4). Farmer's practice, which gave the lowest percent of potential population (45.3) was initially affected by wide row spacing and use of non-certified seed resulting in low germination. Soil type did not affect plant population; however farmer's practice gave the lowest populations in both soils (Table 5 ).

Number of cobs: Treatment had a significant $(P \leq 0.001)$ effect on number of cobs (Table 4$)$. Farmer's practice, Farmyard manure and $\mathrm{N}$ treatments gave the lowest cob numbers and were not significantly different. This was followed by NP and NPK treatments. Highest cob number was given by optimal fertilizer treatment. Soil type had no significant effect on number of cobs (Table 5).

Grain yield: Treatment was highly significant $(P \leq 0.001)$ on maize grain yield (Table 4$)$. Farmer's practice gave the lowest grain yield $\left(2.8 \mathrm{t} \mathrm{ha}^{-1}\right)$

followed by treatments farmyard manure, NP, NPK and $\mathrm{N}$ which were between them not significantly different. Highest grain yield was from optimal fertilizer treatment (Table 4). Farmyard manure, NP, NPK and $\mathrm{N}$ gave grain yield advantage ranging from 3.2 to 3.7 t above farmer's practice compared to optimal fertilizer treatment which gave a $6.4 \mathrm{t}$ yield advantage over farmer's practice.

Soil type was highly significant $(P \leq 0.001)$ on maize grain yield (Table 5). In nearly all the cases, Alfisols' treatments doubled the grain yield of the corresponding Ultisols' treatments. Farmer's practice gave lowest yield in both soils: $3.7 \mathrm{t} \mathrm{ha}^{-1}$ in Alfisols compared to $1.9 \mathrm{t} \mathrm{ha}^{-1}$ in Ultisols. Similarly, in both the soils, NPK, N, NP and farmyard manure treatments gave second highest grain yield. Optimal fertilizer treatment gave highest yield in both soils. Application of farmyard manure in Alfisols had a $4.3 \mathrm{t}$ yield advantage over farmer's practice compared to a $2.0 \mathrm{t}$ yield advantage in Ultisols. Similarly application of $\mathrm{N}$ had a $4.4 \mathrm{t}$ yield advantage over farmer's practice in Alfisols compared $2.2 \mathrm{t}$ in Ultisols.

100-seed weight: Treatment had no significant effect on 100-seed weight (Table 4) but soil type had a highly significant effect seed weight $(P \leq 0.01)$. Alfisols gave higher seed weight compared to Ultisols (Table 5 ). The lowest seed weight in Alfisols was treatment $\mathrm{N}$ while the lowest in Ultisols was NP treatment. Optimal fertilizer treatment gave the highest seed weight in both soils: $24.1 \mathrm{gm}$ in Alfisols and $25.5 \mathrm{gm}$ in Ultisols.

Stover yield: Treatment was highly significant $(P \leq 0.01)$ on maize stover yield (Table 4). Farmer's practice gave $7.3 \mathrm{tha}^{-1}$, followed by a category of treatments comprising of farmyard manure, N, NP and NPK that were not significantly different between them. Optimal fertilizer treatment gave the highest stover yield of $27.6 \mathrm{t} \mathrm{ha}^{-1}$. Similarly, soil type has a highly significant $(P \leq 0.01)$ effect on stover yield (Table 5). In all the cases, Alfisols gave significantly higher stover yield compared to Ultisols. Farmer's practice gave the lowest yield in both soil types. In Alfisols, treatments comprising farmyard manure, $\mathrm{N}$, NP and NPK, though not significantly different between them, gave significantly higher grain yield compared to farmer's practice. Optimal fertilizer treatment gave the highest stover yield of $30.8 \mathrm{t} \mathrm{ha}^{-1}$. In Ultisols, the treatments comprising farmyard manure, $\mathrm{N}$ and NP though not significantly different among them, gave significantly higher stover yield compared to farmer's practice. This was followed by NPK (16.5 t ha $\left.{ }^{-1}\right)$ and optimal fertilizer $\left(24.4 \mathrm{t} \mathrm{ha}^{-1}\right)$. Application of NPK had a stover yield advantage of 13.4t ha $\mathrm{ha}^{-1}$ (Alfisols) and $10.5 \mathrm{t} \mathrm{ha}^{-1}$ (Ultisols) over farmer's practice while farmyard manure had a yield advantage of $11.7 \mathrm{t} \mathrm{ha}{ }^{-1}$ (Alfisols) and $6.2 \mathrm{t} \mathrm{ha}^{-1}$ (Ultisols).

Plant height: Treatment had a highly significant $(P \leq 0.01)$ effect on maize plant height (Table 4). Optimal fertilizer treatment gave the tallest plants (3.0 $\mathrm{m})$ compared to farmer's practice $(1.9 \mathrm{~m})$. Apart from farmer's practice, all other treatments were not significantly different. Soil type had no significant effect on plant height. 
Table 4. Effect of farmyard manure and inorganic fertilizers on maize plant population, percentage of potential population, number of cobs, grain yield (t/ha), 100-seed weight (gm), stover yield (t/ha) and plant height $(\mathrm{m})$ on on-farm trial in western Kenya during wet season of 2006.

\begin{tabular}{|l|c|c|c|c|c|c|c|}
\hline Treatment & Population/ha & $\begin{array}{c}\text { \% of potential } \\
\text { population }\end{array}$ & $\begin{array}{c}\text { Number of } \\
\text { cobs/ha }\end{array}$ & $\begin{array}{c}\text { Grain yield } \\
\text { (t/ha) }\end{array}$ & $\begin{array}{c}\text { 100-seed } \\
\text { weight (gm) }\end{array}$ & $\begin{array}{c}\text { Stover yield } \\
\text { (t/ha) }\end{array}$ & $\begin{array}{c}\text { Plant height } \\
\text { (m) }\end{array}$ \\
\hline Farmer's practice & 22,151 & 45.3 & 20,977 & 2.8 & 21.6 & 7.3 \\
\hline Farmyard manure+1/2 N & 32,965 & 65.1 & 25,051 & 6.0 & 21.2 & 1.9 \\
\hline NP & & & & & & \\
\hline NPK & 33,558 & 66.2 & 27,643 & 6.2 & 20.2 & 17.2 & 2.7 \\
\hline N & 34,780 & 68.8 & 28,606 & 6.5 & 22.1 & 19.2 & 2.6 \\
\hline Optimal fertilizer & 35,485 & 69.8 & 25,495 & 6.1 & 20.8 & 18.2 & 2.5 \\
\hline Mean & 37,447 & 73.8 & 34,977 & 9.2 & 24.8 & 27.6 & 3.0 \\
\hline LSD (P<0.05) & 32,731 & 64.8 & 27,124 & 6.1 & 21.8 & 17.6 & 2.6 \\
\hline
\end{tabular}

Table 5. Effect of farmyard manure and inorganic fertilizers on maize plant population at harvest, percent of potential population, number of cobs, grain yield, 100-seed weight, stover yield and plant height on Alfisols and Ultisols in Kakamega during wet season of 2006.

\begin{tabular}{|c|c|c|c|c|c|c|c|c|c|c|c|c|c|c|}
\hline \multirow[t]{2}{*}{ Treatment } & \multicolumn{2}{|c|}{ Population/ha } & \multicolumn{2}{|c|}{$\begin{array}{l}\text { \% of potential } \\
\text { population }\end{array}$} & \multicolumn{2}{|c|}{ Number of cobs/ha } & \multicolumn{2}{|c|}{ Grain yield (t/ha) } & \multicolumn{2}{|c|}{ 100-seed wt (gm) } & \multicolumn{2}{|c|}{ Stover yield (t/ha) } & \multicolumn{2}{|c|}{ Plant height (m) } \\
\hline & Alfisols & Ultisols & Alfisols & Ultisols & Alfisols & Ultisols & Alfisols & Ultisols & Alfisols & Ultisols & Alfisols & Ultisols & Alfisols & Ultisols \\
\hline F.P & 16,593 & 27,704 & 34 & 57 & 12,444 & 17,778 & 3.7 & 1.9 & 22.3 & 20.9 & 8.4 & 6.0 & 1.4 & 2.3 \\
\hline NPK & 33,556 & 36,000 & 64 & 74 & 27,704 & 29,481 & 8.3 & 4.7 & 22.9 & 21.4 & 21.8 & 16.5 & 2.6 & 2.6 \\
\hline FYM & 35,111 & 30,815 & 67 & 63 & 27,259 & 22,815 & 8.0 & 3.9 & 22.6 & 19.7 & 20.1 & 12.2 & 2.6 & 2.6 \\
\hline NP & 36,296 & 30,815 & 69 & 63 & 29,037 & 26,222 & 8.1 & 4.2 & 21.7 & 18.8 & 20.5 & 13.7 & 2.8 & 2.5 \\
\hline O.F & 37,111 & 37,778 & 70 & 77 & 34,519 & 35,407 & 11.8 & 6.6 & 24.1 & 25.5 & 30.8 & 24.4 & 3.2 & 2.7 \\
\hline $\mathrm{N}$ & 39,556 & 31,407 & 76 & 64 & 29,926 & 21,037 & 8.1 & 4.1 & 20.6 & 21.0 & 22.5 & 13.9 & 2.6 & 2.4 \\
\hline Mean & 33,037 & 32,419 & & & 26,814 & 25,457 & 8.0 & 4.2 & 22.4 & 21.2 & 20.7 & 14.5 & 2.5 & 2.5 \\
\hline $\operatorname{LSD}(P<0.05)$ & Ns & ns & ns & ns & $\mathrm{ns}$ & $\mathrm{ns}$ & 1.0 & 1.0 & 1.2 & 1.2 & 2.6 & 2.6 & $\mathrm{~ns}$ & Ns \\
\hline
\end{tabular}

F.P =Farmer's practice; FYM = Farmyard manure; O.F =Optimal fertilizer 


\section{(ii) Dry season}

Plant population: Treatment had a significant $(P \leq 0.002)$ on plant population at physiological maturity (Table 6). Farmyard manure treatments gave the highest population $(41,763)$; treatments optimal fertilizer, N, NP and NPK were not significantly different. Soil type also had a significant $(P \leq 0.003)$ effect on population. In both soils, farmyard manure gave the highest populations (Table 7). In Alfisols, N, NP, NPK and optimal fertilizer treatments were not significantly different. In Ultisols, $\mathrm{N}$ gave the lowest population (31,111 per ha) followed by optimal fertilizer. In general, plant population was higher during the dry season compared to the wet season.

Cob yield: Treatment had significant effect on cob yield (Table 6). Treatments N, NP and optimal fertilizer gave the lowest cob yield and were not significantly different. Farmyard manure and NPK gave the highest number of cobs. Soil type exhibited no significant effect on cob yield (Table 7). Similarly, treatment showed significant effect on cobs per plant (Table 6). However, only NPK gave a higher significantly different value (Table 6). Soil type showed no significant effect on cobs per plant.

Grain yield: During the dry season, treatment had no effect on grain yield (Table 6). However, $N$ gave the lowest yield followed by NP. The highest, though not significantly different was NPK $\left(1.9 \mathrm{t} \mathrm{ha}^{-1}\right)$. Soil type had a significant effect on grain yield (Table 7 ). In all the cases, Ultisols gave higher yield compared to Alfisols. In Alfisols, only the treatment optimal fertilizer gave a significantly higher yield of $2.4 \mathrm{t} \mathrm{ha}^{-1}$. In Ultisols, farmyard manure gave the highest yield of $2.7 \mathrm{tha}^{-1}$. N gave the lowest yield $\left(1.8 \mathrm{t} \mathrm{ha}^{-1}\right)$.

100-seed weight: While, treatment had no significant effect on 100-seed weight (Table 6), soil type exhibited very significant effect on seed weight $(P \leq$ 0.002) (Table 7)

\section{DISCUSSION:}

Plant population is a direct influence of many factors including source of seed, condition of soil tilth at sowing, row spacing, and soil condition and type of fertilizer used at the time of planting. Many smallholder farmers, besides using recycled or nonimproved seed, don't prepare land to fine tilth, plant at very wide row spacings, all of which lead to low population. During growth stages, heavy winds can also lodge plants. In this study, during wet season, farmer practice gave significantly lower population compared to other treatments. During dry season, farmyard manure gave significantly higher population than the rest of treatments. Organic fertilizers have been reported to buffer soils and can increase water retaining ability leading to enhanced germination and vigorous plant growth (Spaccini et al. 2002). Reduced population observed on fertilizer treatments could have been due to seed scorching by fertilizer at planting.

Number of cobs per plant has a direct effect on the final grain yield. Our findings indicate that farmyard manure is very effective in production of cobs particularly during dry season when the cobs were more compared to inorganic treatments. This could be due to adequate and balanced supply of plant nutrients. This confirms the findings of Tasneem Khaliq et al. (2004) and Shah and Arif (2000).

During both seasons, FYM had about $100 \%$ cob yield advantage over farmer's treatment. Yield contribution from FYM was not different from N, NP and NPK. This indicates that FYM can provide adequate and balanced supply of nutrients just like inorganic fertilizers. Tasneem et al. (2004) and Tolessa and Friesen (2001) reported a similar observation. Alfisols gave comparatively higher cob yield during long rains than short rains.

Optimal application of fertilizer (N, 200; P, 60; K, 120; $\mathrm{Mg}, 20 ; \mathrm{B}, 5 \mathrm{~kg} \mathrm{ha}^{-1}$ ) gave highest cob, grain and stover yields during both seasons on Alfisols. However in the long run, soil will become more acidic. Lungu (2008) reported that continuous application of $120 \mathrm{~kg} \mathrm{~N} \mathrm{ha}^{-1}$ after only for years not only made Alfisols more acidic, but also decreased the exchangeable bases ( $\mathrm{Ca}$ and $\mathrm{Mg}$ ) in the soil. In both soils, FYM plus $30 \mathrm{~kg}$ of $\mathrm{N} \mathrm{ha}^{-1}$ provided maize yield equivalent to that for N, NP and NPK treatments. This indicates that there would be a very significant saving to farmers if they used farmyard manure and side-dressed with $30 \mathrm{~kg}$ of $\mathrm{N} \mathrm{ha}^{-1}$. This finding is consistent with studies conducted by Abunyewa, et al. (2007), Aggarwal et al. (1997) and Materechera and Morutse (2009). 
Agric. Biol. J. N. Am., 2010, 1(4): 430-439

Table 6. Effect of farmyard manure and inorganic fertilizers on maize population, percent of potential population, number of cobs, cobs per plant, grain yield and plant height on a trial in western Kenya during dry season of 2006.

\begin{tabular}{|c|c|c|c|c|c|c|c|}
\hline Treatment & Population/ha & $\begin{array}{l}\% \text { of potential } \\
\text { population }\end{array}$ & $\begin{array}{c}\text { Number of } \\
\text { cobs/ha }\end{array}$ & Cobs/plant & $\begin{array}{l}\text { Grain yield } \\
\text { (t/ha) }\end{array}$ & $\begin{array}{c}\text { 100-seed } \\
\text { wt (gm) }\end{array}$ & $\begin{array}{c}\text { Plant } \\
\text { height }(\mathrm{m})\end{array}$ \\
\hline $\mathrm{N}$ & 33,541 & 66.0 & 20,508 & 0.59 & 1.3 & 20.8 & 1.7 \\
\hline Optimal fertilizer & 35,986 & 71.3 & 27,174 & 0.74 & 1.9 & 24.8 & 1.9 \\
\hline NP & 36,226 & 71.8 & 25,287 & 0.71 & 1.5 & 20.2 & 1.7 \\
\hline NPK & 39,467 & 78.1 & 31,249 & 0.79 & 1.9 & 22.1 & 1.8 \\
\hline Farmyard manure $+1 / 2 \mathrm{~N}$ & 41,763 & 83.3 & 29,063 & 0.69 & 1.6 & 21.2 & 1.7 \\
\hline Mean & 37,396 & 74.1 & 26,656 & 0.70 & 1.6 & 21.8 & 1.7 \\
\hline LSD (P<0.05) & 7,033 & - & 7,171 & 0.15 & Ns & ns & ns \\
\hline
\end{tabular}

Table 7. Effect of farmyard manure and inorganic fertilizers on maize population, percent of potential population, number of cobs, cobs per plant, grain yield , 100-seed weight and plant height on Alfisols and Ultisols on a trial in western Kenya during dry season of 2006.

\begin{tabular}{|c|c|c|c|c|c|c|c|c|c|c|c|c|c|c|}
\hline \multirow[t]{2}{*}{ Treatment } & \multicolumn{2}{|c|}{ Population/ha } & \multicolumn{2}{|c|}{$\begin{array}{c}\% \text { of potential } \\
\text { population }\end{array}$} & \multicolumn{2}{|c|}{$\begin{array}{c}\text { Number of } \\
\text { cobs/ha }\end{array}$} & \multicolumn{2}{|c|}{ Cobs/plant } & \multicolumn{2}{|c|}{ Grain yield (t/ha) } & \multicolumn{2}{|c|}{ 100-seed wt (gm) } & \multicolumn{2}{|c|}{ Plant height (m) } \\
\hline & Alfisols & Ultisols & Alfisols & Ultisols & Alfisols & Ultisols & Alfisols & Ultisols & Alfisols & Ultisols & Alfisols & Ultisols & Alfisols & Ultisols \\
\hline NP & 34,537 & 37,926 & 65 & 81 & 23,889 & 26,667 & 0.7 & 0.7 & 1.6 & 2.3 & 21.7 & 18.8 & 1.7 & 1.7 \\
\hline $\mathrm{N}$ & 36,000 & 31,111 & 68 & 65 & 22,519 & 18,519 & 0.6 & 0.6 & 1.6 & 1.8 & 22.7 & 21.4 & 1.7 & 1.7 \\
\hline Optimal & 36,593 & 35,407 & 71 & 72 & 28,296 & 26,074 & 0.8 & 0.7 & 2.4 & 2.6 & 22.6 & 19.7 & 1.9 & 1.7 \\
\hline NPK & 37,630 & 41,333 & 73 & 86 & 29,333 & 33,185 & 0.8 & 0.8 & 2.0 & 2.6 & 22.9 & 19.5 & 1.7 & 1.9 \\
\hline $\begin{array}{l}\text { FYM + 1/2 } \\
N\end{array}$ & 40,741 & 42,815 & 81 & 88 & 28,370 & 29,778 & 0.7 & 0.7 & 1.6 & 2.7 & 24.1 & 25.5 & 1.8 & 1.7 \\
\hline Mean & 37,100 & 37,718 & 76 & 78 & 26,481 & 26,845 & 0.7 & 0.7 & 1.8 & 2.4 & 22.8 & 21.0 & 1.8 & 1.7 \\
\hline $\begin{array}{l}\text { LSD } \\
(P<0.05)\end{array}$ & 2,237 & 2,237 & - & - & ns & $\mathrm{ns}$ & $\mathrm{ns}$ & $\mathrm{ns}$ & 0.4 & 0.4 & 1.2 & 1.2 & $\mathrm{~ns}$ & $\mathrm{~ns}$ \\
\hline
\end{tabular}

Optimal = Optimal fertilizer; FYM = Farmyard manure 
Grain yield is the end result of morphological and physiological processes occurring during growth and development of a crop. The increase in grain yield due to farmyard manure and optimal fertilizer treatments was mainly due to more number of cobs per plant and better grain development due to adequate nutrient supply. Use of farmyard manure and sometimes in combination with inorganic fertilizers gave maximum grain yields (Tasneem et al. 2004; Tamayo et al. 1997).

Lower 100-seed weight was obtained from Ultisols. The higher weight observed in Alfisols was due to the comparatively balanced supply of nutrients throughout the grain filling and development period.

Plant height is among the most important biomass yield components of maize crop. Besides being a genetic trait, it is also a reflection of nutrient availability, management and favorable prevailing weather. Plant height was significantly different among treatments during the wet season. Farmer practice gave the shortest plants. This was probably due to differences in genetic traits of the varieties. Farmers either plant landrace varieties or recycled improved hybrids; recycled seeds could have lost the genetic potential for height. The fact that optimal fertilizer treatment gave the tallest plants is an indication that abundant nutrient supply is directly correlated to growth. Farmyard manure and inorganic fertilizers produced taller plants. Akinrinde et al (2004), while working on Nigerian Alfisols reported similar result. Stover yield followed a similar trend like grain yield.

\section{CONCLUSION:}

The extra maize yield obtained from use of inorganic fertilizer over farmyard manure is not substantial enough to justify their use. Addition of nitrogen fertilizer failed to increase maize yields in Ultisols apparently due to the decline in soil $\mathrm{pH}$ and consequently inefficient utilization of added nutrients. For smallholder farmers, FYM will be a favourable source of nutrients as it is cost effective, locally available and also effective in reducing the exchangeable Al.

\section{REFERENCES}

Abunyewa, A. A., C. Osei and E.Y.Safo. 2007. Integrated manure and fertilizer use, maize production and sustainable soil fertility in sub humid zone of west Africa. Journal of Agronomy, Vol. 6, Issue 2, 2007.
Aggarwal, R. K., Praveen-Kumar and J.F. Power. 1997. Soil and Tillage Research, Volume 41, Issues 1-2, pp. 43-51.

Akinrinde, E. A., Onanuga, O. A., Bello, O. S and Obigbesan, G. O. 2004. Efficiency of indigenous ground phosphate rocks, organic fertilizers and their mixtures for maize performance in two Nigerian Alfisols. Moor Journal of Agricultural Research, vol. 4, No. 1 (2004).

Henao, J. and Baanante, C. 2006. Agricultural Production and Soil Nutrient Mining in Africa: Implications for resource conservation and policy development. IFDC Tech. Bull. Muscle Shoals, AL. USA.

Liasu, M. O., Ogundare, A. O. and Ologunde, M. O. 2008. Effect of soil supplementation with fortified Tithonia mulch and directly applied inorganic fertilizer on growth and development of potted okra plants. AmericanEurasian Journal of sustainable Agriculture, 2(3): 264270, 2008.

Lungu, O.I.M. and Dynoodt, R.F.P. 2008. Acidification from long-term use of urea and its effect on selected soil properties. African Journal of Food Agriculture Nutrition and Development. Vol. 8. No. 1. 2008

Materechera, S. A. and Morutse, H. M. 2009. Response of maize to phosphorus from fertilizer and chicken manure in a semi-arid environment of South Africa. Experimental Agriculture (2009), 45: 261-273.

Olabode, O. S., Ogunyemi S., Akambi, W. B., Adesina, G. O., and Babajide, P.A. 2007. Evaluation of Tithonia diversifolia (Hemsl. A. Grey) for soil improvement. World Journal of Agricultural Sciences 3(4): 503-507.

Shah, K. P. and Arif, M. 2000. Management of organic farming: Effectiveness of farmyard manure and nitrogen for maize productivity. Sarhad J. Agric., 16:461-5.

Shepherd, K.D, Ndufa, J.K., Ohlsson, E, Sjogren, H., and Swinkels, R. 1997. Adoption potential of hedgerow intercropping in maize-based cropping systems in the highlands of western Kenya. I. Background and agronomic evaluation. Exp. Agric. 33, 197-223.

Spaccini, R., A. Piccolo, J.S.C. Mbagwu, T.A. Zena, and C.A.Igwe. 2002. Influence of addition of organic residues on carbohydrate content and structural stability of some highland soils in Ethiopia. Soil Use Manage., 18:404-411.

Stroomgard, P. 1991. Soil nutrient accumulation under traditional African Agriculture in Miombo Woodland of Zambia. Trop. Agric. (Trinidad). 1991: 6(1): 74-80.

Swift, M. J., Seward, P. D., Frost, P.G.H., Qureshi, J.N., and Muchena, F.N. 1994. Long-term experiments in Africa: Developing a Database for sustainable land use under global change. In: Long-term experiments in Agricultural and Ecological Sciences, R.A.Raleigh and A.E Johnston (Eds.). CAB International, Wallingford, UK, pp. 229-251. 
Agric. Biol. J. N. Am., 2010, 1(4): 430-439

Tamayo, V. A., A. R. Munoz and R. N. Parsad. 1997. Organic fertilizer to maize on alluvial soils in moderate climate. Actualidades Corpoica, 108: 19-24 (Field Crop Abstract 51: 3970; 1998).

Tasneem, K., Tariq, M., Kamal, J., and Masood, A. 2004. Effectiveness of farmyard manure, poultry manure and nitrogen for corn productivity. International Journal of Agriculture and Biology. 1560-8530/2004/06-2-260-263.
Tolessa, D. and D.K. Friesen. 2001. Effect of enriching farmyard manure with mineral fertilizers on grain yield of maize at Bako, western Ethiopia. Seventh Eastern and Southern Africa Regional Maize Conference. 11$15^{\text {th }}$ February, 2001. Pp. 335-337.

Wikipedia. 2008.

http://soils.usda.gov./technical/classification/orders/alfis ols/html. 